\title{
Screening of Some Foliar Chemical Insecticides against White Fly (Bemisia tabaci) on Tomato at Metema District, North Gondar, Ethiopia
}

\author{
Eshetu Agegnehu*, Yenus Ousma, Asrat Ayalew \\ Department of Plant Sciences, Faculty of Agriculture, University of Gondar, Gondar, Ethiopia \\ Email: ${ }^{*}$ agegnehueshetu@yahoo.com
}

Received 8 February 2014; revised 5 April 2014; accepted 13 May 2014

Copyright (C) 2014 by authors and OALib.

This work is licensed under the Creative Commons Attribution International License (CC BY). http://creativecommons.org/licenses/by/4.0/

(c) (i) Open Access

\begin{abstract}
Tomato is one of the vegetable crops growing in Ethiopia and important cash crops for small scale growers with a potential for increasing incomes in rural areas, improving the living standards and creating employment opportunities for women and youth. Vegetables in tropical countries are the crops which are often attacked most seriously by arthropod pests. Among the major insect pests, white flies, one of a serious leaf-sucking pest, cause direct damage to plants by sucking plant sap. The experiment was conducted in farmer's field with supplementary irrigation at Aftete-Kumer locality in Metema District since 2011/12 to select effective foliar insecticide for white fly control. The experiment was initiated with 5 treatments such as 4 foliar insecticides and control. Foliar chemical insecticides such as Ethiosulfan $35 \%$ EC, Ethiothoate $40 \%$ EC, Ethiolathion $50 \%$ EC and Metasystox 250\% EC were used with rate of 2, 1.5, 1.5 and 0.9 milliliter per plot respectively and arranged by using RCBD with three replications. Melka shola tomato variety was used in this study. Post spray count was carried out three times at 2,5 and 7 days after applying the insecticides. All data were analyzed by using SAS computer software. Plots sprayed with Ethiothoate and Ethiolathion showed less significant difference on stand counting at harvesting with mean number of plants of 48.3 and 41.6 per plot respectively as compared to plots sprayed with Ethiosulfan (39.60), Metasystox (37.6) and Control (37). All treatments were not shown significant difference on pre-spraying count of adult white flies. In case of post-spray count of adult white flies, Ethiothoate showed highly significant difference $(p<0.05)$ with least number of white flies population (1.6 per leaf) followed by Ethiolathion ( 2 per leaf). The highest number of adult white flies was recorded from control (25) and Metasystox (16.6) followed by Ethiosulfan (14.3). Regarding yield, there was significant difference $(p<0.05)$ between treatments. The highest yield was obtained
\end{abstract}

${ }^{*}$ Corresponding author.

How to cite this paper: Agegnehu, E., et al. (2014) Screening of Some Foliar Chemical Insecticides against White Fly (Bemisia tabaci) on Tomato at Metema District, North Gondar, Ethiopia. Open Access Library Journal, 1: e370.

http://dx.doi.org/10.4236/oalib.1100370 
from Ethiothoate (401.6 grams per plot) and Ethiolathion (356.67 grams per plot) followed by Metasystox (119.6 grams per plot) and Ethiosulfan (113.3 grams per plot). The lower yield was obtained from control (81.6 grams per plot). Ethiothoate and Ethiolathion have shown highest efficacy in controlling tomato white fly through reducing the population.

\section{Keywords}

\section{Foliar Insecticides, Tomato, White Fly}

\section{Introduction}

Vegetable crops are valuable sources of vitamins, minerals and proteins especially to a country like Ethiopia where the people experience malnutrition due to heavy dependence on cereals such as tef (Eragrostis tef), maize (Zea maize), wheat and other cereals [1]. Ethiopia has a variety of vegetable crops grown in different agro ecological zones produced through commerce as well as small farmers both as a source of income as well as food. However, the type is limited to few crops and production is concentrated to some pocket areas.

In spite of this, the production of vegetables varies from cultivating a few plants in the backyards for home consumption up to a large-scale production for domestic and export markets [2]. The tomato is now grown worldwide for its edible fruit and for optimum growth in different condition. According to FAOSTAT, 126 million tons of tomatoes were produced in the world in 2007 [3]. China, the largest producer accounted for about one fourth of the global output, followed by United States of America and Turkey.

Tomato is among the vegetable crops grown in Ethiopia and important cash crops for small scale growers with a potential for increasing incomes in rural areas, improving the living standards and creating employment opportunities for women and youth. This crop can be grown all year round. Potato, onion, tomato, garlic, shallot, pepper, are among the leading vegetable crops grown in Amhara region [4]. According to the CSA [5] 501599.14 ha was under fruit (47990.34 ha) and vegetable (453608.8 ha) crops production in Ethiopia. Among the vegetables, tomato covered 5341.58 ha. The total area under some crops in Ethiopia like tomato production has been reduced by about $22 \%$ and productivity by about $15 \%$ in 2005 as compared to that in 2004 . This is mainly due to the prevalence of severe viral and viral like disease accompanied by absence of effective control measures so far [6].

Vegetables in tropical countries are the crops, which are often attacked most seriously by arthropod pests [7]. Among the major insect pests, white flies, one of a serious leaf-sucking pest, cause direct damage to plants by sucking plant sap and removing plant nutrients, thereby weakening the plants. Damage may be more severe when plants are under water stress. In addition, they often produce large quantity of honeydew that leads to the growth of sooty mould on the lower leaves, blocking or reducing the photosynthetic capacity of the plants. The honeydew also contaminates the marketable part of the plant, reducing its market value. Infested plants may wilt; turn yellow in color, become stunted or die when white fly infestations are severe or of long duration. White fly transmits serious virus diseases on cassava, cotton, tobacco, tomato, beans, chillies, and sweet potatoes. This white fly is vector of a range of leaf curle diseases inducing viruses in Eastern and Southern Africa including tomato yellow leaf curle virus [8].

According to Schmutterer [9], white fly has a very wide range of cultivated and wild-plants (e.g. Malvaceae, Solanaceae, Cucurbitaceae and leguminous) to be among alternative hosts for this pest. Both adults and nymphs suck the plant sap. The honeydew excreted by the juvenile stage which covers the leaves results in decrease both in yield and in quantity. Two hundred adults of white flies per 10 leaves indicate that spraying, using recommended insecticides, is required. With the increase in temperature during April and May, the pest infestation increased markedly. On the other hand, the high $\mathrm{RH}\left(80 \%\right.$ - 90\%), coupled with relatively high temperature $\left(36^{\circ} \mathrm{C}\right.$ $-38^{\circ} \mathrm{C}$ ) was found to favor the development and a sharp increase of WF population during September-October [10]. Tropical regions offer a unique agro-ecological environment for B. tabaci to fully express its reproductive potential. Temperature, rainfall and air humidity are normally much higher than that in temperate areas, and photoperiod varies only slightly throughout the year. Since temperature is fairly constant but quite high, and insects are poikilothermic, B. tabaci can breed continuously, giving rise to very high densities and overlapping 
generations [11]. In contrast to the majority of white fly species, B. tabaci has the ability to acquire and transmit over 200 different viruses, mainly begomoviruses, which cause significant yield losses in important crops such as tomato, bell and hot peppers, beans, and various cucurbits including melon and squash. Bemisia tabaci can rapidly disseminate viruses in the field even when populations are not appreciable, and cause severe crop damage in susceptible plantings [11].

White fly has expanded its distribution area enormously and is the number one pest in many crops, such as cucurbits, tomatoes and cotton in many warm regions and in ornamental crops in temperate climates [12]. Any compound capable of keeping white flies away from susceptible plants reduces the possibility of virus inoculation and subsequent disease expression. Protection can be achieved either by feeding deterrent (acting after contact) or by repellent (acting at a distance, as vapors) substances [13].

Tomato growing is one of the most promising areas for horticulture expansion and development in Metema woreda. However, insect pests and diseases are the main bottle neck to hinder the scaling up of horticultural crops in Metema district. Among these limiting factors, recently white fly is one of the major insect pests severely attacking the leaves of tomato plant and transmitting viral diseases as vector via reducing yield. According to the office of agricultural and rural development, most growers are discouraged to produce tomato due to the problem of white fly. There are no so far efforts to manage white fly. The present study, therefore determines effective foliar insecticide against white fly.

\section{Materials and Methods}

\subsection{Site Description}

The experiment was conducted in Metema district of Amhara Regional State. It is located about $900 \mathrm{~km}$ North West of Addis Ababa and about $180 \mathrm{~km}$ west of Gondar town. The district has an international boundary of more than $60 \mathrm{~km}$ distance between Ethiopia and Sudan. The site is situated at latitude $12^{\circ} 57^{\prime} \mathrm{N}$ and longitude $36^{\circ} 11$ 'E.

The total population of the district is 91,216 [14]. The altitude of Metema ranges from 550 to 1608 meters above sea level. The topography of the district is almost flat with $2 \%-5 \%$ slope and the soil color is black (80\%), red (15\%) and grey-brown (5\%). The maximum and the minimum annual temperature range between 22 and 28 degree Celsius respectively. The daily temperature is high during the months of March to May reaching as high as 43 degree Celsius. The rainy season extend from June to September. The mean annual rainfall of the area ranges from about 850 to 1100 mm [14]. The study location was indicated in “Figure 1".

\subsection{Experimental Materials and Design}

The experiment was conducted by using irrigation in tomato growing areas of Metema district especially at Aftete-Kumer locality where white fly is the main bottle neck on tomato production in 2011 to 2012. Five treatments such as Ethiothoate 40\% EC, Ethiolathion 50\% EC, Metasystox 250\% EC, Ethiosulfan 35\% EC foliar insecticides and control were evaluated against white fly. Spraying of insecticides was started when each leaf of the plant contained 20 white flies. Plots were sprayed two times with interval of 15 days after transplanted to the production area by following the recommended rate, Ethiothoate 40\% EC 2 liters per hectare, Ethiolathion 50\% EC 2 liters per hectare, Metasystox 250\% EC 600 milliliter per hectare and Ethiosulfan 35\% EC 2.5 liters per hectare. The insecticides were applied in early morning. Detailed descriptions of the insecticides were indicated in “Table 1". The experiment was arranged in randomly complete block design (RCBD) with three replications. Plot size of $3 \mathrm{~m} \times 5 \mathrm{~m}$ was used and plots has 1.5 meter apart from each other. Spacing between plants and rows were 30 centimeters and 1metere respectively. Each plot has 5 rows and 50 plants. All recommended crop packages were followed as required. Melka shola improved tomato variety was collected from Melkasa Agricultural Research Center and it is important raw materials for industry as well as for fresh consumption. It was used in this experiment and the seeds sown in naturally white fly infested areas. Tomato seedling was raised on 5 meters long and 1 meter width nursery bed.

The seedlings were transplanted when they got 15 centimeters height with two true leaves. Sampling was carried out along a diagonal or zigzag lines moving over rows and choose a plant at random.

Counting of white fly was done by keeping shadow off the plant and carefully turned the leaf over by the tip of the leaf blade. Ten plants were assessed randomly from each plot for collecting data. 


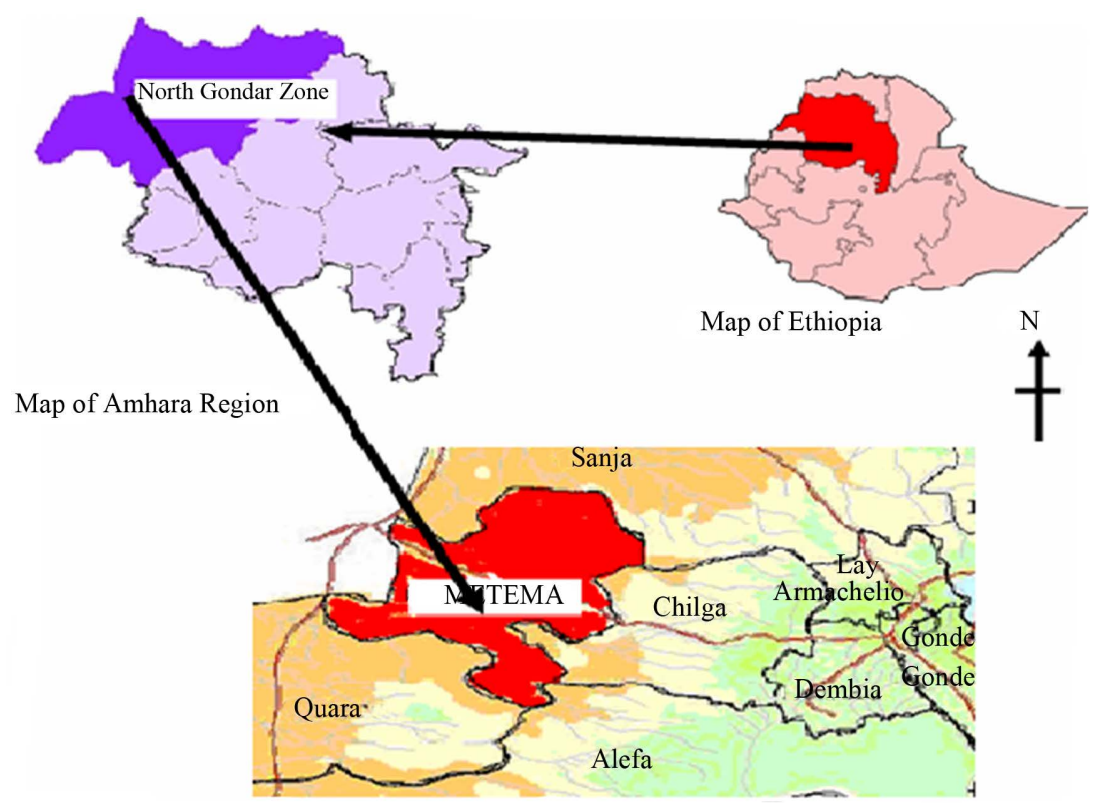

Figure 1. Map of the study area (Amhara region and Metema district).

Table 1. Detailed descriptions of insecticides.

\begin{tabular}{ccccc}
\hline \multicolumn{1}{c}{ Trade name } & Common Name & Active Compositions & Supplier Company \\
\hline Ethiothoate 40\% EC & Ethiothoate/Dimethoate & $\begin{array}{c}\text { Organophosphate, Cholinestrase } \\
\text { inhibitor (Dimethoate, Cyclohexanone and xylene) }\end{array}$ & $\begin{array}{c}\text { Adamitulu Pesticide } \\
\text { Company, Ethiopia }\end{array}$ \\
Ethiolathion 50\% EC & $\begin{array}{c}\text { Ethiolathion/Malathion } \\
\text { (Malathion: 0,0-dimethyl phosphorodithioate } \\
\text { of diethyl mercaptosuccinate) }\end{array}$ & $\begin{array}{c}\text { Adamitulu Pesticide } \\
\text { Company, Ethiopia }\end{array}$ \\
Metasystox 250\% EC & Metasystox & Oxydemeton-methyl(Organophosphate) & Bayer Crop Science AG, Germany \\
Ethiosulfan 35\% EC & Ethiosulfan/Endosulfan & Alfa \& Beta-Endosulfan(Techn) and solvent & $\begin{array}{c}\text { Adamitulu Pesticide } \\
\text { Company, Ethiopia }\end{array}$ \\
\hline
\end{tabular}

\subsection{Data Collected}

- Number of plants per plot/Stand counting/at harvesting

- Counting of white fly/number of white fly per individual sampled plants at pre and post spraying

- Farmers perceptions about the experiment and

- Farmers perceptions about tomato production and protection in their areas

- Yield record per plot/gram per plot/

\subsection{Statistical Analysis}

The analysis of variance for all treatments were carried out using SAS version 9.0 (2008) statistical computer packages to examine the presence of statistically significant differences among treatments. Least Significant Differences (LSD) was employed to identify treatments that are significantly different each other. The analysis of variance was made using model for randomized complete block design [15].

\section{Result and Discussion}

\subsection{Field Experiment}

Evaluation of some foliar insecticides against white flies was conducted at Kumer-Aftete locality in Metema dis- 
trict farmer's field since 2011/2012 by using irrigation. In this experiment four foliar insecticides were tested along with water spray treatment (control). The infestation of white flies was very high during early stage of crop development and it increased alarmingly and reached the peak at crop maturity. Due to early appearance of the pest, two times spray applications were made to observe the efficacy of the insecticides against white flies. Plots sprayed with Ethiothoate and Ethiolathion showed less significant difference on stand counting at harvesting with mean number of plants of 48.3 and 41.6 per plot respectively as compared to plots sprayed with Ethiosulfan (39.60), Metasystox (37.6) and Control (37).

All treatments were not shown significant difference on pre-spraying count of adult white flies. In case of post-spray count of adult white flies, Ethiothoate showed highly significant difference with least number of white flies population (1.6 per leaf) followed by Ethiolathion (2 per leaf). The highest number of adult white flies was recorded from control (25) and Metasystox (16.6) followed by Ethiosulfan (14.3). Regarding yield, there was significant difference between treatments.

The highest yield was obtained from Ethiothoate (401.6 grams per plot) and Ethiolathion (356.67 grams per plot) followed by Metasystox (119.6 grams per plot) and Ethiosulfan (113.3 grams per plot). The lower yield was obtained from control (81.6 grams per plot) indicated in below in the "Table 2".

\subsection{Farmers' Evaluation and Preferences towards the Experiment}

Farmers were actively participated in the field experiment from site selection of hot spot areas of white fly up to harvesting. They evaluated the field experiment at different phases of the experiment such as before and after spraying of foliar chemical insecticides at early stage of the crop after transplanted to production site, at flowering, at fruiting and harvesting time based on their criterion. Majority of farmers participated during field evaluation by considered the performance of the crop in terms of white fly infestation, white fly damage and yield, those plots sprayed with Ethiothoate and Ethiolathion foliar insecticides showed good performance in yielding, least ravage and damage of white fly as indicated them. They also suggested that the foliar insecticides should be integrated with screening of different varieties of tomato as well as other management options for sustainable management of tomato white fly.

\subsection{Farmers' Perceptions}

Informal survey about tomato production and protection status was carried out in Aftete-Kumer locality along with the main research activities since 2011 to 2012. From site selection up to harvesting, farmers around the research site were actively participated and evaluated the research activities. Some farmers were informally interviewed about tomato production and protection status in their areas. Most interviewed farmers were familiarized about white fly problems as well as the magnitude and factors influencing the problems caused by it. Tomato crops cultivating in sandy soil are more exposed to high infestation of white flies as compared to those cultivating in vertisoil/clay/based on the information gathered from interviewed farmers. The main reason as mentioned during interviewing that moisture stress is the main cause for increasing the ravage and damage of white flies. So the problems of white flies is high in crops cultivating in fields have more sandy soil (which has less

Table 2. The effect of Insecticides on the population of tomato white flies, stand count as well as yield at Kumer-Aftete, Metema district.

\begin{tabular}{|c|c|c|c|c|}
\hline Treatments & $\begin{array}{l}\text { Pre-spray count of adult } \\
\text { white flies (mean) per leaf }\end{array}$ & $\begin{array}{l}\text { Post-spray count of adult } \\
\text { white flies (mean) per leaf }\end{array}$ & $\begin{array}{c}\text { Stand count at } \\
\text { harvesting (mean) }\end{array}$ & $\begin{array}{l}\text { Yield Kg/plot } \\
\quad \text { (mean) }\end{array}$ \\
\hline Ethiosulfan 35\% EC & 8 & 1.6 & 48.3 & 0.4 \\
\hline Ethiothoate $40 \%$ EC & 7.6 & 2 & 41.6 & 0.35 \\
\hline Ethiolathion 50\% EC & 7.3 & 14.3 & 39.6 & 0.11 \\
\hline Metasystox 250\% EC & 8 & 16.6 & 37.6 & 0.12 \\
\hline Control & 6.3 & 25 & 37 & 0.08 \\
\hline LSD & 2.49 & 4.41 & 3.59 & 32.4 \\
\hline CV (\%) & 2.3 & 2.3 & 2.3 & 2.3 \\
\hline
\end{tabular}


capacity to hold water) as compared to vertisoil. Tomato Crops cultivating in fields which has more vertisoil resists the problems of white flies because of high water holding capacity. In addition to these majority of farmers indicated that the main problems in tomato production are lack of quality and improved seeds supply. Farmers are purchasing seeds from illegal seed suppliers who dispense without any information as well as poor quality (less seed germination capacity and viability). These bottlenecks are also aggravating the problems of white flies on tomato crops through decreasing performance of the crops. Poor performance of the seedling at early stage leads to less tolerance to the damages caused by white flies. Generally, farmers were indicted that white fly problems and lack of quality seed supply are one of the major obstacles hampering scaling up of tomato production in their areas.

\section{Conclusion and Recommendation}

This study was initiated with the objectives to determine effective foliar insecticide against white fly. Our present research focused on chemical insecticides and since there is little information on this important insect pest and its management method, there is a need to investigate further management options and approaches. However, based on the overall results of the experiment, Ethiothoate and Ethiolathion have shown highest efficacy in controlling tomato white fly through reducing the population via increasing yields. The active ingredient Dimethoate is biodegradable. It undergoes rapid degradation in the environment and in waste water treatment plants. Dimethoate has a potentially high mobility in soil but is relatively unstable. Degradation products are not mobile in soil. It does not bioaccumulate. Malathion is also with half-lives in soil ranging from 1 to 17 days as well as half-life on foliage of various fruits and vegetables ranging from less than 1 to nearly 9 days. The extractable residues of Malathion in soil decline rapidly due to volatilization and metabolism by soil microbes. Both insecticides are applied two times before flowering stage (vegetative stage) of the crop which is sensitive for white flies attack. Even if these insecticides are applied during flowering and fruiting stage of the crop (near to harvest), there are recommended days intervals before utilization of the crop. Generally, organophosphate insecticides are very less residue effects on food and food products. Therefore, these foliar insecticides can be safely recommended as protection method against white fly as well as should be promoted for further evaluation with other management options as integral component for sustainable management of white fly in tomato growing areas of Metema district.

\section{Acknowledgements}

The study was conducted by the financial support of University of Gondar.

\section{References}

[1] Anonymous (2005) Export Products of Ethiopia. Ministry of Information Press and Audiovisual Department, Addis Ababa.

[2] Dawit, A., Abera, D., Lemma, D. and Chemdo, A. (2004) Domestic Vegetable Seed Production and Marketing. Research Report No 5, EARO, Ethiopia, 17 p.

[3] FAOSTAT (2007) An Open Access Journal Published by ICRISAT. http://faostat.fao.org/faostat/

[4] CSA (2006) Area and Production of Major Crops. Agricultural Sample Enumeration Survey, Addis Ababa.

[5] CSA (2008) Area and Production of Major Crops. Agricultural Sample Enumeration Survey, Addis Ababa.

[6] Anonymous (2005) Agricultural Sample Survey Report on Area and Production of Crops (Private Peasant Holdings). The FDRE Statistical Bulletin 331, Vol. 1, Central Statistic Authority (CSA), Addis Ababa.

[7] Emana Getu (2007) New Report of Recommendations for Improving Horticultural Marketing in Ethiopia. In: Gebremedhin, H., Ed., Drylands Coordination Group (DCG), Norway.

[8] Legg, J., Gerling, D. and Neuenschwander, P. (2003) Biological Control of Whiteflies in Sub-Saharan Africa. In: Biological Control in IPM System in Africa, CAB International, Wallingford, 87-100.

[9] Schmutterer, H. (1969) Pests of crops in Northeast and Central Africa with particular reference to the Sudan. Gustav. Fischer Verlag, Stuttgart, Portland.

[10] Ahmed, M.M.M. (2000) Studies on the Control of Insect Pestsin Vegetables (Okra, Tomat and Onion) in Sudanwith Special Reference to Neem Preparation. Faculty of Agrarwissenschaften, Ökotrophlogie und Umweltmanagement, University of Giessen, Giessen. 
[11] Anderson, P.K. and Morales, F.J. (eds.) (2005) Whitefly and Whitefly Borne Viruses in the Tropics: Building a Knowledge Base for Global Action. Publication 341, CIAT, Colombia, 351 p.

[12] Gerling, D. (ed.) (1990) Whiteflies: Their Bionomics, Pest Status and Management, Intercept Ltd, Andover.

[13] Naranjo, S.E. and Ellsworth, P.C. (2001) Challenges and Opportunities for Pest Management of Bemisia tabaci in the New Century. Crop Protection, 20, 707-869. http://dx.doi.org/10.1016/S0261-2194(01)00107-7

[14] IPMS (Improving Productivity and Market Success) (2005) Metema Learning Site Diagnosis and Program Design (Unpublished). ILRI (International Livestock Research Institute), Addis Ababa.

[15] SAS Institute (2008) Statistical Analytical Systems SAS/STAT User’s Guide. Version 8(2), SAS Institute Inc., Cary. 